\title{
VEG OR NON-VEG? FROM BAZAARS TO HYPERMARKETS IN INDIA
}

\author{
Johan Fischer ${ }^{*}$ \\ Department of Social Sciences and Business, Roskilde University, \\ House 23.2, Postbox 260, 4000 Roskilde, Denmark \\ E-mail: johanf@ruc.dk
}

Published online: 15 January 2019

To cite this article: Fischer, J. 2019. Veg or non-veg? From bazaars to hypermarkets in India. International Journal of Asia Pacific Studies 15 (1): 1-32, https://doi.org/10.21315/ijaps2019.15.1.1

To link to this article: https://doi.org/10.21315/ijaps2019.15.1.1

\begin{abstract}
This paper reviews the literature on vegetarianism (veg) and meat-eating (non$v e g$ ) in India. My central aim is to explore how vegetarianism and meat-eating are addressed in existing research in order to identify gaps and pave the way for a new research agenda on the complex and changing relationship between vegetarianism and meat-eating at different levels-consumers, markets and regulators-in contemporary India. Why and how Hindus eat meat is not well understood and much of the existing literature often assumes that not only does the concept of ahimsa (noninjury to all living creatures), cow veneration and banning of cow slaughter prevent Hindus from eating meat, but also that the relationship between vegetarianism and meat-eating is relatively simple and stable among Hindu groups. What is more, India is a major exporter of meat and water buffalo beef in particular. In Hindu nationalist discourses, as well as scholarly studies, Hindu meat-eating is often seen as exceptional and/or due to spiritual, ritual or religious circumstances, rather than as an everyday practice. However, the complex and contested relationship between vegetarianism and meat-eating is as topical as ever: in 2011, the Indian state made it mandatory that all processed food products should bear marks to indicate whether products are vegetarian (green) or non-vegetarian (brown) and with the rise of consumer culture in super/hypermarkets, these logos are ubiquitous on packagings throughout India. I argue that the above aspects have been central in the making of a powerful vegetarian ideology that has seduced much of the scholarship on vegetarianism into suggesting that vegetarianism in India is dominant among Hindus. The central research question concerns why and how a vegetarian ideology
\end{abstract}


has created the hegemonic view of vegetarianism as proper Hindu practice and how Hindus respond to and are affected by this over time. In the last part of the paper, I report on fieldwork conducted in the city of Hyderabad and using this local setting I explore veg and non-veg among consumers, markets and regulators.

Keywords: India, vegetarianism, meat-eating, retail, consumer culture

\section{INTRODUCTION ${ }^{* *}$}

In November 2017, I was in the audience when the Prime Minister of India, Narendra Modi, delivered his speech at the major food fair World Food India held in central Delhi, which attracted more than 2,000 participants and 400 exhibitors from 20 countries. Modi, who has been Prime Minister since 2014, belongs to the Hindu nationalist Bharatiya Janata Party (BJP), is a strict vegetarian, and promotes vegetarianism as a national project, declared that World Food India would provide a "glimpse of the opportunities that await you in India" and the sampling of "some of our most delightful cuisine, which has stimulated taste buds across the world." Modi then went on to explain that India is the world's largest producer of milk and the second largest when it comes to rice, wheat, fish, fruits and vegetables. In a broader perspective, "India is today one of the fastest growing economies in the world. (...) Increasing urbanisation, and a growing middle class, are resulting in an ever-growing demand for wholesome, processed food." Modi ended by saying that "I assure you of my whole-hearted support, whenever required. Come. Invest in India. The place with unlimited opportunity from farm to fork. The place to produce, process, and prosper. For India, and for the world."

Modi failed to mention that India is also one of the world's largest and fastest-growing producers of meat and water buffalo beef in particular, and that within the last couple of decades the country has witnessed a meat revolution: meat is being sold and consumed throughout the country, and particularly among the urban Hindu middle class. Modi's omission points to a much larger issue in that it sustains a vegetarian ideology, that is, India was, is and should be a vegetarian nation. Brahmin groups, the Hindu priestly caste within the Varna (caste/class) system, who traditionally promote vegetarianism, and the Hindu nationalist movement of which Modi is at the forefront, have carefully supported this idea, accepting at face value the notion that most Hindus are, or desire to be, vegetarians while Muslims and lower castes are not and do not wish to be. 
Why and how Hindus eat meat is not well understood and much of the existing literature often assumes that not only does the concept of ahimsa (non-injury to all living creatures), cow veneration and banning of cow slaughter prevent Hindus from eating meat, but also that the relationship between vegetarianism and meat-eating is relatively simple and stable among Hindu groups. What is more, India is a major exporter of meat and water buffalo beef in particular. In Hindu nationalist discourses, as well as scholarly studies, Hindu meat-eating is often seen as exceptional and/or due to ritual or religious circumstances, rather than as an everyday practice. Indian scholarship on vegetarianism is often carried out by higher caste Hindus who may favour vegetarian principles on the one hand and Western scholars on the other-for example, The Bloodless Revolution (Stuart 2015) explores how vegetarianism, influenced by India, has been a potent social force over the last 400 years in Europe. Vegetarianism was Gandhi's first political cause as a born-again vegetarian, and the author draws on the Indian case to build a humanitarian case for vegetarianism that unites both the animal welfare and ecological perspectives, as well as that of human self-interest. In this paper I focus mainly on vegetarianism in India and not so much the West.

The complex and contested relationship between vegetarianism and meat-eating is as topical as ever: in 2011, the Indian state made it mandatory that all processed food products should bear marks to indicate whether products are vegetarian (green) or non-vegetarian (brown) and with the rise of consumer culture in super/hypermarkets these logos are ubiquitous on packagings throughout India.

A note on ideology before I proceed. Obviously, ideology is a big and diverse topic, but Balibar's (1991: 95) ideas about the fusing of national and religious identities fit the topic of Indian vegetarianism. He argues that national ideology involves "ideal signifiers" such as the name of the fatherland on to which the sense of the sacred and the affects of love, respect, sacrifice and fear, which have cemented religious communities, are transferred. Balibar writes that "national identity, more or less completely integrating the forms of religious identity, ends up tending to replace it, and forcing itself to be "nationalised." At the core of the nationalisation of Hinduism and Hinduness lies the question of proper Hindu practice. Especially vegetarianism (cow veneration, banning of cow slaughter and vegetarian regulation) has taken on significance as signifier in the nationalisation of Hinduism in India. Even if statistics in India show that most Hindus eat meat, the national ideology that India is, or should be, a vegetarian nation is promoted and upheld. This paper reviews the literature on vegetarianism (veg) and non-vegetarianism/ 
meat-eating (non-veg) among Hindus in India. This distinction is ubiquitous and crucial in India: historically, many Hindus have been vegetarians, and maintaining the boundary between veg and non-veg is socially, politically and economically essential. I argue that the above aspects have been central in the making of a powerful vegetarian ideology that has seduced much of the scholarship on vegetarianism into suggesting that vegetarianism in India is dominant among Hindus. The central research question concerns why and how a powerful vegetarian ideology has created the hegemonic view of vegetarianism as proper Hindu practice and how Hindus respond to and are affected by this over time.

In a notification issued by Food Safety and Standards Authority of India (FSSAI) under The Ministry of Health and Family Welfare (2011: 29), "Non-Vegetarian Food" is defined in the following way: "an article of food which contains whole or part of any animal including birds, fresh water or marine animals or eggs or products of any animal origin, but excluding milk or milk products, as an ingredient" whereas "Vegetarian Food" is "any article of Food other than Non-Vegetarian Food as defined in regulation" (2011: 30). Moreover, "Every package of 'Non-Vegetarian' food shall bear a declaration to this effect made by a symbol and colour code as stipulated below to indicate that the product is Non-Vegetarian Food. The symbol shall consist of a brown colour filled circle" that must have a minimum specified diameter to be "inside a square with brown outline having sides double the diameter of the circle." Conversely, "Every package of Vegetarian Food shall bear a declaration to this effect by a symbol and colour code as stipulated below for this purpose to indicate that the product is Vegetarian Food. The symbol shall consist of a green colour filled circle" that must have a minimum specified diameter to be "inside the square with green outline having size double the diameter of the circle." Finally, it is specified in detail that the size of green/brown marks must match the overall surface of products in order to be clearly visible (2011, 35). Throughout the document, specifications for packaging and labelling are detailed. Not only in India but also globally, billions of Indian products carry green or brown marks (Figure 1).

Paradoxically, this grand scheme was implemented at a time when the retail market was being liberalised and standardised, with drastic but largely unexplored effects on consumer culture in different social groups: consumers, markets and regulators. In the last part of the paper, I focus on this paradox in connection with some preliminary findings in my ongoing research project on veg and non-veg in Hyderabad in the state of Telangana. In this local setting, I explore veg and non-veg among consumers, markets and regulators. 
My preliminary findings suggest that the relationship between veg and nonveg is being redefined in contemporary India: the long-held idea that the more individuals and social groups follow a vegetarian lifestyle, the higher the social status they will enjoy, is breaking down. What is more, veg and non-veg are increasingly individual lifestyle choices rather than determined by religious orthodoxy - and ironically all this takes place in the context of strict state regulation of veg (green) and non-veg (brown).

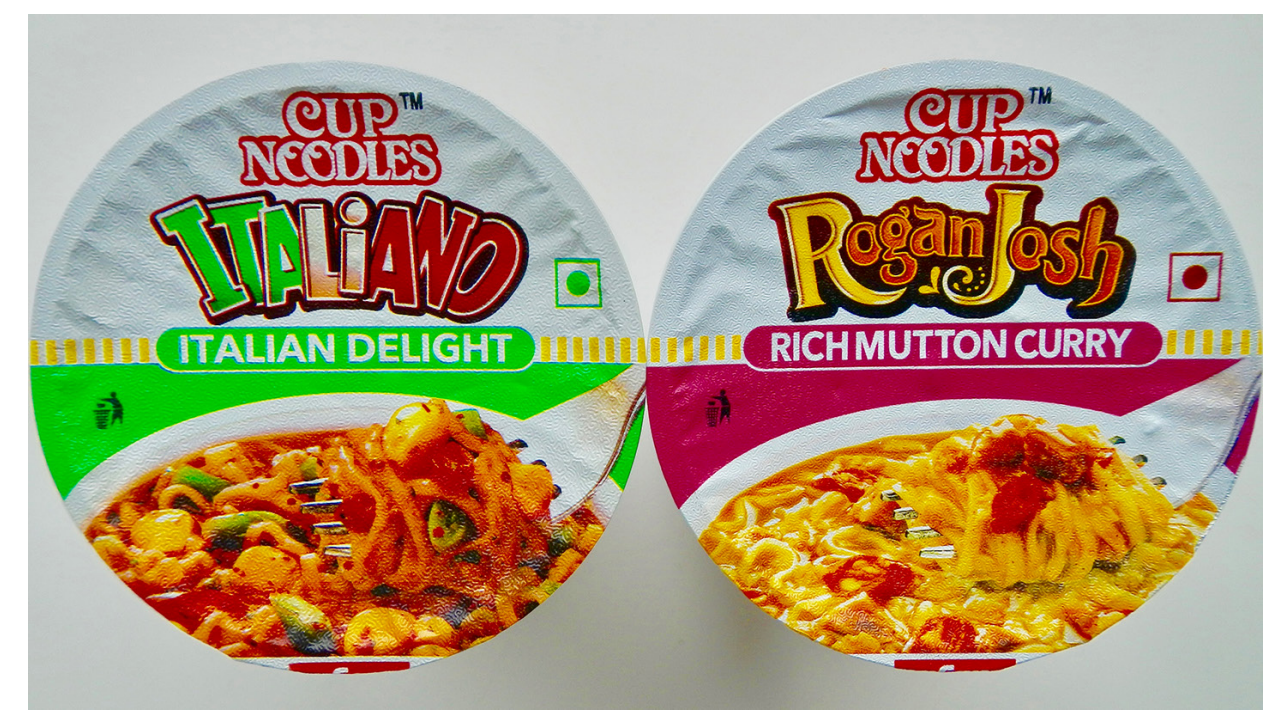

Figure 1: Veg (left) and non-veg (right) instant noodles in a Hyderabad hypermarket. Source: Johan Fischer.

This paper is divided into five sections. Following this introduction, I turn to Indian food systems with specific reference to veg and non-veg. I then discuss the ongoing retail revolution and changing consumer culture that surrounds Indian food systems. The next section presents the results of my 2017 survey on veg and non-veg in Hyderabad in the state of Telangana in South India, and reflects on some preliminary findings from my ongoing ethnographic fieldwork conducted there. The conclusion ties the findings of the article together and outlines a new research agenda on the complex and changing relationship between veg and non-veg in India and beyond.

\section{INDIAN FOOD SYSTEMS: VEGETARIAN AND NON- VEGETARIAN}

Before I proceed to discuss Indian food systems a word on vegetarianism and meat-eating. Essentially, a vegetarian is a person who eats no flesh, but there are subcategories such as lacto-vegetarians (who consume dairy products, but 
not eggs) and ovo-vegetarians (who consume eggs, but not dairy products). Of course, there are major variations across time, space and social differentiation and this is especially the case in India.

Meat plays a vital role when discussing vegetarianism. Meat has always evoked multiple and ambivalent meanings (Leroy and Praet 2015), and to many people meat is synonymous with "real" food (Fiddes 1991: 14). At the same time, it is mostly particular types of meat that are taboo. Meat is often considered prestigious and vital for nutrition on the one hand, and dangerously immoral and potentially unhealthy on the other (Fiddes 1991: 2). Sutton (2017) argues that in spite of much anthropological reflection on cultural rules and functional systems surrounding meat-eating, ethnographies of meat-eating are scarce but necessary in order to explore how daily practices of vegetarianism are shaped by a whole range of factors such as household dynamics, risk, trust/blame, emotions, taste, modern life, as well as the relationship between humans and animals. In sum, studies of vegetarianism and meat-eating, for the most part, focus on more generalised and stable notions of preference, but rarely explore the everyday practices, changes and complexities that arise between veg and non-veg.

Khare's (1966) classic study of Indian food systems explores how Indian institutions, values, cultures, sacred/secular aspects as well as nutritional, economic, political and historical processes constrain everyday food practices. All these aspects comprise the Indian food system and shape the classification and categorisation of food, as in the case of veg/non-veg. The study provided a larger and more comprehensive understanding of South Asian food systems and a culturally sensitive approach to specific foods and nutritional issues: public distribution systems, the sacred channels of food, control, scientific developments and technology as well as global food availability.

Similarly, Appadurai $(1981 ; 1988)$ explored "gastro-politics," that is, how beliefs about food encode complex sets of social and moral propositions when tracing the formation of "the national cuisine" and middle-class and public food consumption. He focused specifically on the heightened importance of institutional, large-scale, global, multi-ethnic and public food consumption in India. Class transformation and changed cuisines flourishing in Indian cities are supported by changes in the technology and economy of cooking, for example a large and growing food industry selling ingredients and instant foods. These transformations should all be seen in the context of the commercialisation of agriculture, transport, marketing and credit that are making it possible to expand food markets and systems in India. All this meets in the twin processes of regional and ethnic specialisation and the development 
of an overarching national cuisine. Ray and Srinivas (2012) explore these processes of middle-class formation, nation building, and changing foodways in social and cultural worlds between the local and the global. In a similar vein, Gupta (2003) argues that agriculture, food production, modernity and nation-building are inseparable.

Anjaria (2016) examines why street food vendors in Mumbai call supermarkets such as Big Bazaar "showrooms" in which products are wrapped in plastic and appear to be artificial. I draw attention to this fascinating study because very little research has been done in these Indian "showrooms" or standardised shopping spaces. What is more, in these supermarkets meat is either not sold or only a limited frozen selection is available, whereas hypermarkets offer a wide variety of meat and fish. In hypermarkets, middleclass consumers spend a considerable portion of their time and earnings on global consumer goods like Western-style clothing, consumer electronics, motorbikes and other luxuries, and are keen to display their latest acquisitions actively in public (Fernandes 2006; Fuller and Narasimhan 2007).

Of course, caste is still of relevance when exploring food systems in India, but right now social mobility is radically changing the scenario. In Dumont's classic study, Homo Hierarchichus, he argues that vegetarianism was by its "nature easily integrated into the ideas about pure and impure" (Dumont 1966: 150). Here, vegetarianism is equated with the dominant caste in the Hindu worldview and underpins the cohesiveness of the hierarchy principle in Hindu society. "Vegetarian" conventionally describes the Indian uppermiddle class as well as upper-caste Hindus/Brahmins, who pride themselves on their higher religious status and distinguish themselves from lower castes by their vegetarian eating habits (Sadana 2007). Thus, being vegetarian can convey high status, and animal sacrifice is ideologically devalued in relation to vegetarian worship (Fuller 1992: 88).

Ahimsa originally signified non-violence to living beings and had nothing to do with vegetarianism (Alsdorff 2010 [1962]). In the Brahmin Lawbook of Manu, leeks, garlic, onions and mushrooms are also forbidden as they can be considered "heating" and may arouse sexual desire. Ahimsa was based on a "magico-ritualistic" dread of destroying life, but the origins and source of ahimsa have not yet been explored satisfactorily. The author traces ahimsa in legal texts and in the gradual emergence and assertion of vegetarianism and cattle protection (as we shall see below), arguing that vegetarianism and the cow taboo must be separated. Historically, Buddhism and Jainism reinforced Hindu understandings of vegetarianism, but Alsdorff warns that as there are no clear answers regarding its origins, scholars should be careful to avoid 
"rationalist" answers and to essentialise vegetarianism as an unequivocally Hindu phenomenon.

Simoons' classic study Eat Not This Flesh (1994) explores various forms of vegetarianism in India throughout history: from meat-eating to strict vegetarians who reject meat, fish and eggs as well as many other types of food. Traditionally, top social status was given to strict Jain and Hindu vegetarianism. Exceptions are Hindu Dravidians in South India (Simoons 1994), the Reddi of Hyderabad, and tribal peoples who breed pigs for sacrifice, but Hindu influence was halting this (Simoons 1994). Cow veneration in India comprises the world's most important surviving cattle cult rejection of beef as human food (Simoons 1994), even though cattle are important in Indian economic life. The origins of cow veneration and the reasons for the ban on beef are not only contested, but also dynamic and changing over time. For example, Brahmins accepted beef in early history (Simoons 1994).

The sacred cow concept gained impetus from rivalry between Muslims and Hindus at independence and the ban on cow slaughter was incorporated into the Constitution of India Article 48 leading to decades of legal controversy often involving Muslims. Lynchings of Muslims accused of slaughtering, selling and eating cows are frequent in India (Jaffrelot 2017). Today, cow slaughter is banned in many Indian states. Article 48 mandates the state to prohibit the slaughter of cows in 2005 the Supreme Court of India upheld the constitutional validity of anti-cow slaughter laws enacted by 20 out of 29 Indian states. Violators face six months jail and/or Rupees 1,000 fine. While the export of beef (cow, oxen and calf) is prohibited, the meat of buffalo, goat, sheep and birds is allowed.

India is home to the world's largest concentration of water buffalo. It is important to note the difference between water buffalo and cattle beef or zebu cows (also known as indicine cattle or humped cattle). Since the late 2000s, India's exports of water buffalo beef in particular have expanded rapidly, with the country emerging as the world's largest beef exporter in 2014. This development is due to rising demand for low-cost meat by consumers in developing countries, India's large water buffalo herd and the emergence of private sector and export-oriented Indian processors. Most of India's majority Hindu population (about 80 percent of the population in 2011) does not eat cattle beef (United States Department of Agriculture 2016). A recent survey shows that while less than one percent of Hindus in the Hindi heartland eat beef/buffalo meat, nationally this number is increasing - especially in the southern states (The Hindu 29 October 2016). However, surveys like this one are often flawed as respondents are reluctant to admit to eating beef. 
Based on ethnographic studies in a village in northern India, in 19581959 and 1977-1978, Freed et al. (1981) demonstrated that belief in the sanctity of the zebu cows significantly influenced the demography of cattle and water buffalos in this village, that is, the relationship between Hindus and cows/buffalos were determined by belief and not so much a cultural-ecological and functional framework. Thus, beef in India has to be broken down into cattle beef or buffalo beef.

To sum up, in India cow veneration, the ban on cow beef and largescale and growing meat production are concrete expressions of human cultural perceptions of diverse animals, their social and economic role, and their ritual purity or impurity. To Hindus, "internal pollution" is worse than "touch" pollution since "internal pollution" involves penetration of the body by pollutants, including impure foods. What is more, Hinduism was profoundly affected by the new religions that to a large extent conditioned the emergence of ahimsa (Harris 1977).

To Hindus, food/drink is closely related to bodily substance, health, well-being and purity/pollution (Marriott 1976; Malamoud 1996), as well as to caste, class, gender and kinship. Hindu vegetarianism among different class and caste groups has always been contentious in India, but now the country finds itself at the interface of three major transformations that are fundamentally reshaping conventional forms of vegetarianism: Hindu revivalist agendas; discourses and institutions which are penetrating everyday life and reconfiguring public culture (Hansen 1999); the fact that an increasing number of companies are involved in, and must comply with, rising forms of vegetarian regulation; and the emergence of a new Hindu middle class of about 300 million consumers attentive to the crucial distinction between veg and non-veg. All my middle-class Hindu informants could classify family, friends and colleagues as "veg" or "non-veg." At the same time, long-held notions of vegetarianism as superior, healthy and spiritual are being reconceptualised, and my project unpacks these developments among South Indian Hindus who are not necessarily at the forefront of vegetarian politics or Hindu nationalism as practiced in some Indian states in the north.

Another essential influence on Indian food systems is Gandhi's vegetarianism as an example of gastro-politics, ideology and reason; concretely, the relationship between ahimsa, celibacy and bodily administration and leadership (Alter 2000). Gandhi's programme of social and political action focused on somatic concerns and a biomoral public health imperative (Alter 2000). There is more to vegetarianism than meets the eye: it is not just a matter of personal choice, and it is also quite different from the Brahmanical rationale 
for purity and Jain spirituality (Alter 2000). To Gandhi, a meal should ideally consist of moderate, minimally cooked, unprocessed and quickly prepared ingredients as a simple and natural basis - in this understanding vegetarianism is intrinsically good. While Hindu nationalism is often associated with vegetarianism, at least rhetorically, this was not the case with Vinayak Damodar Savarkar, who in 1923 invented the term Hindutva, that is, a form of political Hinduism that sought to organise and militarise Hindus as a nation. Savarkar saw Gandhi's vegetarianism as effeminate and retrogressive (Nandy 2014).

In recent years, a wave of popular literature and other media products have promoted food often labelled as "spiritual" or "world" cuisine. Although standardised and sanitised forms of vegetarianism have proliferated within the last decade or so, existing research on emergent forms of regulation of the vegetarian market in India (Nickow 2015; Parvathi and Waibel 2016) mostly explore local/community certification initiatives with reference to specific crops and not so much national regulation efforts in relation to processed foods.

In a Special Issue of South Asia: Journal of South Asian Studies (Osella 2008), Indian vegetarianism was explored from a range of perspectives. The editor writes that while subaltern groups are normatively non-veg, many dominant groups are normatively veg, and their vegetarianism is, for them, one of the indices of their superiority and their birth right to privilege. Moreover, there is an understanding that vegetarianism articulates with ideas about Hindu ritual purity, caste pollution, social status and superiority. In effect, the categories of veg (pure) and non-veg (impure) are segregated and thus non-veg is articulated as "objectionable." Another assertion is the association made between vegetarianism and non-violence. This is one of the cornerstones for high-caste Hindu claims to moral, spiritual and personal superiority, and Hindu nationalist discourse commonly claims that Muslims and Dalits are inferior and violent meat-eaters. Dolphijn (2006) has shown why and how meat has become a radical manifestation of political liberation or a counterreaction against the symbolic subordination of meat consumers by powerful upper castes.

Chigateri (2008) argues that the food hierarchy in India relies on a matrix composed of the superiority of the ethic of non-violence, a graded hierarchy of living things, and a belief in the sacredness of the cow, which together produce a conception of necessary food. However, the food hierarchy has to contend with the critique that a Dalit politics of food has to offer, which subverts and disrupts the associations between beef-eating and the violence of "untouchability." The food hierarchy in India would suggest an order of 
superiority that descends from vegetarianism, to meat-eating (but no beef), to beef-eating (Chigateri 2008), and critiques of this food hierarchy are generally aimed at the "hypocrisy" of the non-beef-eating population. Michelutti (2008) shows how the veg/non-veg food distinction among the powerful northern India caste, the Yadavs, enters the nexus of caste and politics. Being vegetarian and worshipping vegetarian deities are important aspects of the formation of an all-India Yadav community. Donner (2008) focuses on the way in which the neo-liberal reforms of the 1990s informed changing lifestyles and consumer orientation with reference to food availability and consumption among urban Indian middle-class households. More specifically, semi-processed foods associated with the "West" were introduced and these were both popular and debated among Bengali middle-class households. The local enterprise, Arambhag Limited, began selling frozen chicken parts, bacon and salami that were seen to be high-status and hygienic compared to produce from the stalls of vendors in the local markets. It should be noted that in India, hygienic is not necessarily the same as "ritually pure" even if these notions are often conflated. Thus, non-veg dishes, which used to be consumed only in restaurants, were now available in shops to be consumed in middle-class nuclear households. Based on material from Madras, Caplan (2008) challenges the idea that vegetarianism is associated with Brahmins and non-vegetarianism with nonBrahmins, arguing that a more complex and changing array of dietary choices exists within the Brahmin and non-Brahmin middle-class populations, as well as a dynamic and flexible set of commensal relations both within and between these groups. Commensality is practiced between vegetarians and nonvegetarians in the home, where some non-Brahmin vegetarian women cook non-veg foods for their husbands and relatives. Desai (2008) investigates how becoming a member of a Hindu religious sect, the Mahanubhav Panth, requires the practice of a veg diet and concludes that the practice of vegetarianism by low-caste/status groups does not necessarily reflect an elite world view. Adopting a veg diet as a consequence of membership of a Hindu religious sect, and living by its rules, protects members from witchcraft and magic. In Klein's (2008) afterword, he argues for more cross-cultural comparisons of meat-eating and vegetarianism, and concludes that people in South Asia make situated decisions to consume or avoid certain foods. Moreover, decisions to eat or accept particular foods may be highly strategic in the broader perspective of historical transformations such as how the transnational food economy, for example, is conditioned by specific economic and cultural contexts.

The Marwaris of Rajasthan are successful merchants, and Babb's (2004) study focuses on trade and its social implications. Babb argues that in India, 
Hindu and Jain trading castes tend to be associated with vegetarianism and non-violent traditions, and that these privileged positions inform the social and political structures of contemporary India. More specifically, these notions form an important part of the social base of Hindu nationalism, which has acquired unprecedented political influence in recent years. Cow protection, the banning of animal sacrifice, and "vegetarian politics" promoted by the BJP and Hindu groups mobilise constituencies around India — often against Muslim beefeaters and butchers. Vegetarian politics is not only a political expression of anti-Muslim prejudice, but also of the culture of trading caste identity.

Giridharadas (2011) shows that in contemporary India, vegetarians are embracing meat and non-vegetarians are turning to vegetarianism, and that these groups do not necessarily define themselves according to caste and faith. These trends are nowhere as visible as in Hyderabad, where they are an expression of a new world of social mobility and aspirations, as well as consumer culture, against the historical backdrop of the fabled Islamic empire.

To my mind, the seminal ethnographic study of meat-eating and vegetarianism is Ghassem-Fachandi's Pogrom in Gujarat: Hindu nationalism and anti-Muslim violence in India (2012), which explores violence against Muslims in the state of Gujarat in 2002 in the context of extreme Hindu nationalism. The book focuses on ahimsa in the media, violent action and everyday life, demonstrating how ethnic and religious differences between Hindus and Muslims were constructed through diet, animal slaughter and religious sacrifice. This detailed ethnographic study shows how the pious, vegetarian Hindus became angered by the stereotypically bloodthirsty and violent Muslims. Modi was Chief Minister in Gujarat and arguably played a role in these atrocities. At the time of Ghassem-Fachandi's fieldwork, restaurants, including McDonald's, started to cater both to vegetarians and non-vegetarians, and when the author returned to Ahmedabad in 2008, new malls and supermarkets had appeared. The practice of vegetarianism seemed to be less vigorously defended as the younger generation of the new middle class seemed to fancy eating meat, even though national interest in vegetarian politics had not dwindled. Actually, this is where my study starts: new and sanitised forms of meat-eating and vegetarianism. A mere three years later, in 2011, the green/brown marks were introduced nationally.

Statistics reveal that even if only 30 percent of the Indian population is strictly vegetarian (Robbins 1999), meat consumption is still very low in India. According to a national survey conducted in 2011, Indians eat on average three to four kilos of meat per person yearly: two kilos of chicken, 
one kilo of mutton and less than half a kilo of beef, compared to the world average of around 43 kilos. Statistics show that the consumption of fish is about three kilos. That said, India is a major producer of meat, and even vegetarian communities rear livestock for the meat market. The BJP's ban on cow slaughter and opposition to meat-eating is an attempt to provide an account of Indian cultural history and meat-eating. Meat has always mattered in India, but the extension of exchange and processing networks for animal products has intensified the age-old cultural contests over the signification of animal flesh. Vegetarianism is not so much a given historical reality in India as it is a claim over the meaning of nature in the Indian economy.

Meat can take on medicinal qualities in Hindu cosmology (Zimmermann 2011), as we shall see below. Closely related to this, I explore how informants understand "nutrition" to function both as a scientific and a spiritual/ethical discipline. Nutrition serves this dual function by providing a range of scientific knowledge about food and the body as "spiritual" disciplines. What is more, subjects of modern dietary science are suffused with ethical and "spiritual" problems through the government of food (Coveney 2000).

Due to urbanisation, the consumption of meat, especially chicken, is increasing in India (Devi et al. 2014). Meat consumption varies across India and it is correlated with cultural factors, such as the dominant religion, ethnolinguistic groups and local castes. Meat consumption is the highest where the percentage of Muslims, Christians, tribal populations or lower castes is highest (Pingali and Khawaja 2004). Several religious and ritual restrictions apply to vegetarianism: a marker of purity and of superior status in the caste system; "auspicious days," that is, two to three days per week without meat, but also on new moon and full moon days; when visiting a major temple or when preparing for a pilgrimage; and a temporary state of what is seen as a "ritual defilement" following the death of a relative or during menstruation. Pork is often seen as impure and is avoided by many consumers. Beef avoidance is still very strong among Hindu families from middle and high castes, and some low caste communities have given up beef eating as a strategy of upward mobility. New and more individual forms of ethical vegetarianism are emerging among the urban middle classes. Sometimes claiming a Western influence, these new forms of vegetarianism intermingle moral, ritual, hygienic and sometimes environmental concerns. Lastly, medical and dietary regulations also account for the low intake of meat in India (Ahmad 2013).

One of the few ethnographic explorations of Hindu meat eating is Dragsdahl's (2016) short study of food consumption and friendship among college youth Hindus in Bengaluru. Young people from the middle classes in 
Bengaluru try to unite friendships, romantic relationships, health/purity beliefs and family relations through food practices. The ambiguity of eggs, selective vegetarianism and contextual meat consumption are hopeful practices through which the contrasts of veg and non-veg, and of caste society in general, are negotiated and mediated.

Classic studies such as Khare's (1966) exploration of meat-eating among the Kanya-Kubja Brahmans of Katyayan Gotra see meat-eating as exceptional among Brahmins. Traditionally, the majority of Brahmins are vegetarians and believe in and praise the concept of vegetarianism, while others are permitted to eat meat based on different types of religious reasoning and rationalisation used to support why they are eating meat.

A recent article by Novetzke (2017) is unique in examining the term "non-veg" (meat/fish, eggs and alcohol). The term originated in Indian English in the early twentieth century to mark menus at restaurants and resorts catering to middle/upper-class British and Indians. "Non-veg" has multiple meanings and it denotes an antinomic position by naming things that do not belong within normal, polite and socially orthodox Hindu practices, while "vegetarian" indicates a "normal" position. Turning to the complexity of actual practices, Novetzke (2017) refers to two studies conducted by the Government of India: the 2006 study on dietary practices across India shows that 60 percent of Indians eat meat (beef [mostly buffalo], mutton, chicken, fish and eggs), while a 1992 study showed that 88 percent of India's Hindus ate meat of some kind.

It is not clear from these statistics if these practices take place in or outside homes, and the data does not seem to be broken down according to religious or ethnic groups. At the same time, the term "non-veg" also involves cultural politics as India is the leading beef exporter in the world (mainly buffalo meat) and this industry is largely undertaken by Muslims and low castes, especially Dalits. Thus, vegetarianism in India reflects a cultural vision of normativity, but not a dominant practice (Novetzke 2017: 367). At the core of vegetarian politics are the dominance of Hindu culture, the notion of India as a "Hindu" place, and the idea that "Hindu" primarily means vegetarian, especially with reference to the practices of high castes and dominant castes and excluding lower castes and Dalits.

The vast majority of the studies discussed above focus on vegetarianism in microsocial contexts and not so much meat-eating. Typically, studies of vegetarianism in India explore Hindu disgust and fascination with traditional meat markets in the bazaar or vegetarianism in Hindu philosophy (Roy 2002). Hindu meat-eating is mostly seen as exceptional and/or generated by certain ritual or religious circumstances rather as an everyday practice - and in 
most cases locations such as Gujarat and Rajasthan, where vegetarianism is widespread among Hindu groups, are seen to be representative of India as a whole. Thus, we see the forceful vegetarian ideology at work here and this is even more visible when turning to the major changes in the marketplace that have taken place over the last couple of decades and it is to that aspect I will now turn.

\section{RETAIL REVOLUTION AND CHANGING CONSUMER CULTURE IN INDIA}

This section discusses how consumer landscapes in India have significantly changed since the early 1990s. The 1991 reforms completely altered landscapes of consumer spaces/goods and economic policies. During a major balance-ofpayments crisis, Prime Minister PV Narasimha Rao's government introduced radical policy changes in the economic sphere that came to be known as "economic reforms" or "liberalisation": trade barriers were significantly lowered, the policy of state regulation of industrial production was effectively dismantled, and investments were significantly liberalised. With this, India abandoned a state-centric development model and embraced a market-oriented one (Maiorano 2015). These transformations also mirror wider societal changes, most notably in the form of increased affluence, material status and the fact that a large number of Indian middle-class women work outside the home while still being in charge of buying groceries and preparing food.

Rao et al. (2016) show that agri-food chains in India are rapidly transforming and that to a large extent, this has been triggered by changes in incomes, consumption and work patterns driven by economic development. Demand-driven chains are replacing the previous supply-driven chains, and new groups of Indian consumers welcome these changes. The gradual liberalisation of the retail sector, coupled with an emphasis on investment and the rise of organised retail, are strengthening agricultural marketing. Most importantly, investments in scientific storage, including grain storage, refrigeration, grading and packaging, are increasing. The entry of foreign players has increased competition and improved professionalism and service, but the enormous size of these players has put pressure on traditional retail and small and medium-sized enterprises in the procurement of goods and services, leading to advantages for the retailing giants. However, as we shall see, butcher's shops still retain their importance in the Indian non-veg landscape. 
Dholakia and Sinha (2005) show how many of India's 13 million smaller retail stores are being supplemented by large malls, especially on the outskirts of cities. In the modern, westernised milieu of these new stores, there is a need to project a strong cosmopolitan image. In transforming urban markets of India, a new landscape for qualitative research, especially employing observational methods, is opening up. These transitions can be conceptualised as a move from a "bazaar economy" to a "standardised" economy (Fanselow 1990) characterised by standardised and substitutable commodities in terms of quality/quantity. Buyers can collect information about highly standardised and economically substitutable commodities prior to purchase through direct comparison, precedent or consultation with other buyers. Hence, in the standardised commodity market, brand names and trademarks work as classificatory devices through which the provenance of goods becomes identifiable and their quality therefore more predictable. With the declining importance of personal loyalty (in butcher's shops and wet markets, for example) in the labour market, the importance of previous experience, training, skills and formal qualifications among staff increases. In standardised shopping spaces such as super/hypermarkets, a vast amount of information is transmitted via product logos and labels. Hence, this form of impersonal shopping warrants detailed information on labels and in the form of green/brown logos, for example. What is more, super/hypermarkets are themselves standardised spaces in terms of design, allowing for the proper handling of goods on the one hand and readiness for audits/ inspections on the other.

I locate my analysis of the complex and changing relationship between veg and non-veg at the interface of the retail revolution and new forms of consumer culture, that is, the broader extension of the Indian consumer goods markets and advertising. In India, the emergence of a new ontology of global consumption was felt most forcefully in advertising images that reflected the desires of individual consumers and simultaneously presented the national community as an aesthetic community (Mazzarella 2003) distinguished by its taste preferences (veg or non-veg), which are most clearly pronounced in the emerging middle class. Indian advertising and marketing professionals Indianised brands and devised new sources of value for products that were suddenly almost too available. Simultaneously, the Indian market sought to achieve professional autonomy vis-à-vis multinational clients. As we shall see, the veg and non-veg binary plays an important role in that respect. Most importantly, perhaps, Hinduism was mobilised as an antidote to globalising consumerism. At the same time, Hindu revivalist agendas, discourses and 
institutions penetrate everyday life and reconfigure public culture (Hansen 1999).

In the post-liberalisation period, "moral consumption" among the emergent middle class is producing a new configuration of capitalism that makes recurrent reference to Hindu doctrine and practice and to the formation of a Hindu subject capable of acting and competing in a neoliberal, but still profoundly religious economic environment. Moral consumption constitutes India's contemporary "divine market" in which commodities are spiritualised and spirituality is subjected to a logic of commodification (Srivastava 2017). Moral consumption and divine economies can be seen as an extension of Swadeshi, that is, the preference for goods produced in India that began in 1905 and also played a major role in the freedom struggle as a rhetorical device in the import substitution strategy and agricultural self-sufficiency pursued by the Indian state from 1950 to 1991 (Hansen 1996). Gandhi added a slightly more generalised meaning of "indigenisation" and Swadeshi was thus linked to materialised nationalist practices. The (Hindu nationalist) resistance to liberalisation and import of foreign goods after 1991 also used the rhetoric of Swadeshi (Hansen 1996) and notions of an agrarian and community-based selfgovernance are central here. An example of this is when the BJP-government in Delhi decided to close down a Kentucky Fried Chicken outlet in Delhi on the peculiar ground that flies had been recovered inside the kitchen premises of the restaurant (Hansen 1996). In continuation of Swadeshi, the ban on cow slaughter and rigorous green/brown regulation can be seen as the deepening of moral economies and divine markets on the one hand and disciplining of imported food products in particular on the other.

The reconfiguration of veg and non-veg reflects India's "aesthetics of arrival" (as we saw in Modi's speech): namely the novelty, visibility and celebration of the post-reform landscape (Kaur and Hansen 2016). On the one hand, vegetarianism is celebrated, promoted and certified by BJP and the state, and on the other meat-eating (and its "brown" regulation) is a sign of prosperity, pluralised markets, reconfigured status/hierarchies, inclusion, social mobility, health and cosmopolitanism. Indeed, a wide range of meat is now available in expensive hypermarkets as well as in traditional butcher's shops.

Within the Indian aesthetics of arrival, veg and non-veg are constantly interpreted in multiple frames-for example, the mandatory marks on food and other products can be seen as a specific disciplinary aesthetics, since all multinational companies exporting to India must brand their food products/ ingredients with these marks. Meat sold in super/hypermarkets is often 
packaged and this is very different from the bazaar or butcher shops. Most recent anthropological studies on India's middle class explore this topic in terms of state and market, stressing the important role that consumption has come to play in the post-liberalisation era since 1991 (Fernandes 2000; Mazzarella 2003; Osella and Osella 2000) or the cultural politics surrounding it (Baviskar and Ray 2011). While these studies are important, there is little empirical research on Hindu consumer cultures in a context of state, market and class transformation.

Indeed, India today qualifies as a Consumers' Republic (Cohen 2004) that plays a key role in reconstructing the nation's economy and reaffirming its democratic values by promoting the expansion of mass consumption. Policymakers, business, labour leaders and civic groups all strive to place mass consumption at the centre of their plans for a prosperous nation. Thus, one may also regard the Food Safety and Standards Authority of India's initiative (under The Ministry of Health and Family Welfare) to make marks on food products mandatory as a means to politically institutionalise production, regulation and consumption. Clearly, this is a sign of the state's bid to become an apparently "honest broker" of consumption (Zukin 2004) which protects the interests of Indian consumers against the constantly increasing inflow of foreign products. Consumers' trust in, and dependence on, the state as an honest broker in consumption legitimates state intervention regarding the right way to shop as well as its guidance in public debates about value. The state now recognises and institutionalises the power residing in commodities as a new and powerful "language of stateness" (Hansen and Stepputat 2001: 37) that helps to shape the state, governance, effects and subjectivities.

\section{GREEN OR BROWN? ON FIELDWORKAND FOOD IN HYDERABAD}

I will now provide a glimpse into my preliminary findings: firstly, a discussion of my survey on veg and non-veg and then a couple of ethnographic examples. Hyderabad was chosen as the primary fieldwork site for several reasons: firstly, the city has experienced the retail revolution and consumer culture as few other places in India have: over the last couple of decades the city has boomed economically and this has led to social mobility among Hindu groups most of all, successful high-tech projects, and a deepening consumer culture. For example, several international super/hypermarket chains such as Star and Spar have opened outlets in the city. What is more, the city embodies a fascinating mix between the Hindu majority and the large Muslim minority. 
To my knowledge, the only study of food and class in Hyderabad is that of Dittrich's (2009) exploration of rapidly changing food consumption patterns and dietary transition. The study shows that due to economic growth, liberalised markets, new lifestyle choices and the presence of local/ multinational super/hypermarkets, consumer demand for a greater variety of food products is increasing. Concerns over food and nutrition security are increasing due to changing food consumption patterns and dietary transition among the urban middle classes. Middle-class diet transformation includes a preference for livestock and dairy products, sugar, fats and oils and highly processed convenience foods and drinks, all of which are readily available in the emerging supermarkets and fast-food outlets as well as pizzas, burgers, sweets and ice cream. A lot has happened since this study, and the retail revolution and changed consumer culture have radically altered the relationship between veg and non-veg.

The initial stage of my fieldwork was quantitative in outlook. A survey conducted in late 2017 among 1,000 informants above the age of 15 in and around Hyderabad mapped food habits with specific reference to veg and non-veg. The survey was based on stratified random sampling in locations such as markets, educational institutions, workplaces and residential areas. Respondents were asked these questions: gender and age; caste; highest level of education; occupation; household size; annual household income; migration; religion; meat/non-meat; eggs/onion/garlic; shopping habits; Hindus and food; health; green/brown logos; and politics. At a later stage these were also the questions I discussed with informants during the ethnographic part of the fieldwork. The main focus is on Hindu respondents. Below, some of the survey findings are summarised in three tables.

Table 1 shows that roughly half of the population is aged between 30 39 and about 20 percent are in the categories 20-29 and 40-49, respectively. The remaining respondents are either under 20 or above 50 years of age. Meat eating is fairly evenly distributed in terms of age and gender. It should be noted that it was more difficult to have women fill in the questionnaire, but nevertheless the tendency is clear-roughly nine out of 10 respondents eat meat. The age distribution also shows that most respondents are old enough to have experienced the major changes in food markets that have taken place over the last two decades or so.

Table 2 shows that in terms of caste and religion over 80 percent of respondents are Hindus, less than 10 percent are Muslims and Christians (who are all meat-eaters) and the remaining respondents are Buddhists and Jains, in that order. Regarding caste, respondents were asked to indicate the caste 
they felt they belonged to. Some informants listed specific caste groups such as Brahmin, while others listed broader categories such as the Open Category (OC): a category that includes people of the Varna system including Brahmin (Priest Community), Kshatriya (Ruler Community) and Vaishya (Business Community). In this category, 220 respondents specified their caste as Brahmin (74), Kamma (65), Reddy (46) and Vyshya (35). Forty percent belonged to the Backward Classes (BC): economically and socially backward classes of Indian society who are mostly Hindus. In the $\mathrm{BC}$ category, more than 90 percent indicate that they eat meat. The BC-C category is exclusively for groups that converted to Christianity and is not actually a caste group. Respondents in this group are from Scheduled Castes. In the OC category, about 75 percent of respondents were meat-eaters. Brahmins account for about 60 percent of meat-eaters.

Table 1: Age and gender distribution in relation to meat eating.

\begin{tabular}{|c|c|c|c|c|c|}
\hline \multirow{2}{*}{\multicolumn{2}{|c|}{ Category }} & \multicolumn{3}{|c|}{ Do you eat meat? } & \multirow{2}{*}{ Total } \\
\hline & & Yes & No & Not answered & \\
\hline \multirow{7}{*}{$\stackrel{8}{\&}$} & Less than 20 & $\begin{array}{c}1 \\
100.0 \%\end{array}$ & $\begin{array}{c}0 \\
0.0 \%\end{array}$ & $\begin{array}{c}0 \\
0.0 \%\end{array}$ & $\begin{array}{c}1 \\
100.0 \%\end{array}$ \\
\hline & 20 to 29 & $\begin{array}{c}179 \\
87.7 \%\end{array}$ & $\begin{array}{c}13 \\
6.4 \%\end{array}$ & $\begin{array}{c}12 \\
5.9 \%\end{array}$ & $\begin{array}{c}204 \\
100.0 \%\end{array}$ \\
\hline & 30 to 39 & $\begin{array}{c}500 \\
90.3 \%\end{array}$ & $\begin{array}{c}27 \\
4.9 \%\end{array}$ & $\begin{array}{c}27 \\
4.9 \%\end{array}$ & $\begin{array}{c}554 \\
100.0 \%\end{array}$ \\
\hline & 40 to 49 & $\begin{array}{c}168 \\
91.3 \%\end{array}$ & $\begin{array}{c}9 \\
4.9 \%\end{array}$ & $\begin{array}{c}7 \\
3.8 \%\end{array}$ & $\begin{array}{c}184 \\
100.0 \%\end{array}$ \\
\hline & 50 to 59 & $\begin{array}{c}39 \\
83.0 \%\end{array}$ & $\begin{array}{c}0 \\
0.0 \%\end{array}$ & $\begin{array}{c}8 \\
17.0 \%\end{array}$ & $\begin{array}{c}47 \\
100.0 \%\end{array}$ \\
\hline & 60 and above & $\begin{array}{c}10 \\
100.0 \%\end{array}$ & $\begin{array}{c}0 \\
0.0 \%\end{array}$ & $\begin{array}{c}0 \\
0.0 \%\end{array}$ & $\begin{array}{c}10 \\
100.0 \%\end{array}$ \\
\hline & Total & $\begin{array}{c}897 \\
89.7 \%\end{array}$ & $\begin{array}{c}49 \\
4.9 \%\end{array}$ & $\begin{array}{c}54 \\
5.4 \%\end{array}$ & $\begin{array}{c}1000 \\
100.0 \%\end{array}$ \\
\hline \multirow{3}{*}{$\begin{array}{l}\dot{\bar{\theta}} \\
\overrightarrow{0} \\
\overrightarrow{0}\end{array}$} & Men & $\begin{array}{c}711 \\
89.4 \%\end{array}$ & $\begin{array}{c}33 \\
4.2 \%\end{array}$ & $\begin{array}{c}51 \\
6.4 \%\end{array}$ & $\begin{array}{c}795 \\
100.0 \%\end{array}$ \\
\hline & Women & $\begin{array}{c}186 \\
90.7 \%\end{array}$ & $\begin{array}{c}16 \\
7.8 \%\end{array}$ & $\begin{array}{c}3 \\
1.5 \%\end{array}$ & $\begin{array}{c}205 \\
100.0 \%\end{array}$ \\
\hline & Total & $\begin{array}{c}897 \\
89.7 \%\end{array}$ & $\begin{array}{c}49 \\
4.9 \%\end{array}$ & $\begin{array}{c}54 \\
5.4 \%\end{array}$ & $\begin{array}{c}1000 \\
100.0 \%\end{array}$ \\
\hline
\end{tabular}


Table 2: Caste and religion in relation to meat eating.

\begin{tabular}{|c|c|c|c|c|c|}
\hline \multirow{2}{*}{\multicolumn{2}{|c|}{ Category }} & \multicolumn{3}{|c|}{ Do you eat meat? } & \multirow{2}{*}{ Total } \\
\hline & & Yes & No & Not answered & \\
\hline \multirow{8}{*}{ Ũ } & $\mathrm{BC}$ & $\begin{array}{c}361 \\
95.8 \%\end{array}$ & $\begin{array}{c}8 \\
2.1 \%\end{array}$ & $\begin{array}{c}8 \\
2.1 \%\end{array}$ & $\begin{array}{c}377 \\
100.0 \%\end{array}$ \\
\hline & $\mathrm{BC}-\mathrm{C}$ & $\begin{array}{c}2 \\
100.0 \%\end{array}$ & $\begin{array}{c}0 \\
0.0 \%\end{array}$ & $\begin{array}{c}0 \\
0.0 \%\end{array}$ & $\begin{array}{c}2 \\
100.0 \%\end{array}$ \\
\hline & $\mathrm{OC}$ & $\begin{array}{c}238 \\
74.6 \%\end{array}$ & $\begin{array}{c}41 \\
12.9 \%\end{array}$ & $\begin{array}{c}40 \\
12.5 \%\end{array}$ & $\begin{array}{c}319 \\
100.0 \%\end{array}$ \\
\hline & $\mathrm{SC}$ & $\begin{array}{c}150 \\
99.3 \%\end{array}$ & $\begin{array}{c}0 \\
0.0 \%\end{array}$ & $\begin{array}{c}1 \\
0.7 \%\end{array}$ & $\begin{array}{c}151 \\
100.0 \%\end{array}$ \\
\hline & ST & $\begin{array}{c}42 \\
100.0 \%\end{array}$ & $\begin{array}{c}0 \\
0.0 \%\end{array}$ & $\begin{array}{c}0 \\
0.0 \%\end{array}$ & $\begin{array}{c}42 \\
100.0 \%\end{array}$ \\
\hline & Muslim & $\begin{array}{c}56 \\
100.0 \%\end{array}$ & $\begin{array}{c}0 \\
0.0 \%\end{array}$ & $\begin{array}{c}0 \\
0.0 \%\end{array}$ & $\begin{array}{c}56 \\
100.0 \%\end{array}$ \\
\hline & Not answered & $\begin{array}{c}48 \\
90.6 \%\end{array}$ & $\begin{array}{c}0 \\
0.0 \%\end{array}$ & $\begin{array}{c}5 \\
9.4 \%\end{array}$ & $\begin{array}{c}53 \\
100.0 \%\end{array}$ \\
\hline & Total & $\begin{array}{c}897 \\
89.7 \%\end{array}$ & $\begin{array}{c}49 \\
4.9 \%\end{array}$ & $\begin{array}{c}54 \\
5.4 \%\end{array}$ & $\begin{array}{c}1000 \\
100.0 \%\end{array}$ \\
\hline \multirow{7}{*}{ 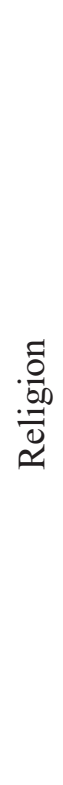 } & Hindu & $\begin{array}{c}727 \\
88.0 \%\end{array}$ & $\begin{array}{c}48 \\
5.8 \%\end{array}$ & $\begin{array}{c}51 \\
6.2 \%\end{array}$ & $\begin{array}{c}826 \\
100.0 \%\end{array}$ \\
\hline & Muslim & $\begin{array}{c}69 \\
100.0 \%\end{array}$ & $\begin{array}{c}0 \\
0.0 \%\end{array}$ & $\begin{array}{c}0 \\
0.0 \%\end{array}$ & $\begin{array}{c}69 \\
100.0 \%\end{array}$ \\
\hline & Christian & $\begin{array}{c}82 \\
100.0 \%\end{array}$ & $\begin{array}{c}0 \\
0.0 \%\end{array}$ & $\begin{array}{c}0 \\
0.0 \%\end{array}$ & $\begin{array}{c}82 \\
100.0 \%\end{array}$ \\
\hline & Buddhist & $\begin{array}{c}3 \\
75.0 \%\end{array}$ & $\begin{array}{c}0 \\
0.0 \%\end{array}$ & $\begin{array}{c}1 \\
25.0 \%\end{array}$ & $\begin{array}{c}4 \\
100.0 \%\end{array}$ \\
\hline & Jain & $\begin{array}{c}0 \\
0.0 \%\end{array}$ & $\begin{array}{c}1 \\
100.0 \%\end{array}$ & $\begin{array}{c}0 \\
0.0 \%\end{array}$ & $\begin{array}{c}1 \\
100.0 \%\end{array}$ \\
\hline & Other & $\begin{array}{c}16 \\
88.9 \%\end{array}$ & $\begin{array}{c}0 \\
0.0 \%\end{array}$ & $\begin{array}{c}2 \\
11.1 \%\end{array}$ & $\begin{array}{c}18 \\
100.0 \%\end{array}$ \\
\hline & Total & $\begin{array}{c}897 \\
89.7 \%\end{array}$ & $\begin{array}{c}49 \\
4.9 \%\end{array}$ & $\begin{array}{c}54 \\
5.4 \%\end{array}$ & $\begin{array}{c}1000 \\
100.0 \%\end{array}$ \\
\hline
\end{tabular}


Table 3: Occupation and household income distribution in relation to meat eating.

\begin{tabular}{|c|c|c|c|c|c|}
\hline \multirow{2}{*}{\multicolumn{2}{|c|}{ Category }} & \multicolumn{3}{|c|}{ Do you eat meat? } & \multirow{2}{*}{ Total } \\
\hline & & Yes & No & Not answered & \\
\hline \multirow{8}{*}{ 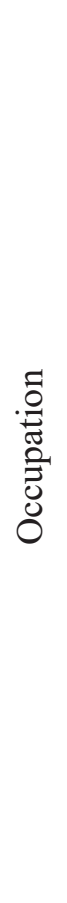 } & Business owner & $\begin{array}{c}88 \\
88.0 \%\end{array}$ & $\begin{array}{c}7 \\
7.0 \%\end{array}$ & $\begin{array}{c}5 \\
5.0 \%\end{array}$ & $\begin{array}{c}100 \\
100.0 \%\end{array}$ \\
\hline & Professional & $\begin{array}{c}264 \\
86.3 \%\end{array}$ & $\begin{array}{c}15 \\
4.9 \%\end{array}$ & $\begin{array}{c}27 \\
8.8 \%\end{array}$ & $\begin{array}{c}306 \\
100.0 \%\end{array}$ \\
\hline & Skilled/semi-skilled & $\begin{array}{c}288 \\
94.4 \%\end{array}$ & $\begin{array}{c}5 \\
1.6 \%\end{array}$ & $\begin{array}{c}12 \\
3.9 \%\end{array}$ & $\begin{array}{c}305 \\
100.0 \%\end{array}$ \\
\hline & Housewife & $\begin{array}{c}77 \\
88.5 \%\end{array}$ & $\begin{array}{c}9 \\
10.3 \%\end{array}$ & $\begin{array}{c}1 \\
1.1 \%\end{array}$ & $\begin{array}{c}87 \\
100.0 \%\end{array}$ \\
\hline & Student & $\begin{array}{c}128 \\
87.1 \%\end{array}$ & $\begin{array}{c}11 \\
7.5 \%\end{array}$ & $\begin{array}{c}8 \\
5.4 \%\end{array}$ & $\begin{array}{c}147 \\
100.0 \%\end{array}$ \\
\hline & Unemployed & $\begin{array}{c}34 \\
97.1 \%\end{array}$ & $\begin{array}{c}1 \\
2.9 \%\end{array}$ & $\begin{array}{c}0 \\
0.0 \%\end{array}$ & $\begin{array}{c}35 \\
100.0 \%\end{array}$ \\
\hline & Others & $\begin{array}{c}18 \\
90.0 \%\end{array}$ & $\begin{array}{c}1 \\
5.0 \%\end{array}$ & $\begin{array}{c}1 \\
5.0 \%\end{array}$ & $\begin{array}{c}20 \\
100.0 \%\end{array}$ \\
\hline & Total & $\begin{array}{c}897 \\
89.7 \%\end{array}$ & $\begin{array}{c}49 \\
4.9 \%\end{array}$ & $\begin{array}{c}54 \\
5.4 \%\end{array}$ & $\begin{array}{c}1000 \\
100.0 \%\end{array}$ \\
\hline \multirow{5}{*}{ 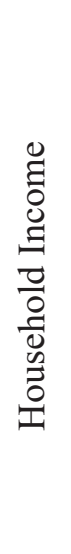 } & Less than $2,50,000$ & $\begin{array}{c}455 \\
94.0 \%\end{array}$ & $\begin{array}{c}18 \\
3.7 \%\end{array}$ & $\begin{array}{c}11 \\
2.3 \%\end{array}$ & $\begin{array}{c}484 \\
100.0 \%\end{array}$ \\
\hline & $2,51,000-5,00,000$ & $\begin{array}{c}382 \\
86.6 \%\end{array}$ & $\begin{array}{c}29 \\
6.6 \%\end{array}$ & $\begin{array}{c}30 \\
6.8 \%\end{array}$ & $\begin{array}{c}441 \\
100.0 \%\end{array}$ \\
\hline & $5,10,000-10,00,000$ & $\begin{array}{c}54 \\
84.4 \%\end{array}$ & $\begin{array}{c}1 \\
1.6 \%\end{array}$ & $\begin{array}{c}9 \\
14.1 \%\end{array}$ & $\begin{array}{c}64 \\
100.0 \%\end{array}$ \\
\hline & $10,01,000$ and above & $\begin{array}{c}6 \\
54.5 \%\end{array}$ & $\begin{array}{c}1 \\
9.1 \%\end{array}$ & $\begin{array}{c}4 \\
36.4 \%\end{array}$ & $\begin{array}{c}11 \\
100.0 \%\end{array}$ \\
\hline & Total & $\begin{array}{c}897 \\
89.7 \%\end{array}$ & $\begin{array}{c}49 \\
4.9 \%\end{array}$ & $\begin{array}{c}54 \\
5.4 \%\end{array}$ & $\begin{array}{c}1000 \\
100.0 \%\end{array}$ \\
\hline
\end{tabular}

Table 3 demonstrates that in terms of occupation and income (business owner/professional/skilled-semi-skilled/housewife/student/unemployed), there is a fairly even distribution of meat-eaters at around 90 percent. However, among a small group of informants in the highest annual income category (above 1,000,000 Rupees), two tendencies can be observed: while half of respondents in this group are meat-eaters, almost 40 percent chose not to answer this question. Thus, among the relatively small group of respondents with the highest incomes, meat-eating is comparatively lower and can be considered a sensitive issue. To a lesser extent, the issue of meat-eating as sensitive can also 
be observed among professionals (mostly IT professionals) and students. The lowest number of meat-eaters is found among "housewives." In sum, survey data show that the higher their income, the more likely respondents are to be vegetarians even if the majority still remain meat-eaters.

Household size and migration (comparing locals and migrants who arrived within the last two years) have an insignificant impact on meat-eating. Respondents were asked about their meat-eating habits, and here we see that 90 percent of meat-eaters consume a complex combination of chicken, mutton, pork, beef and fish. The general trend is that chicken is the most popular meat, followed by mutton and fish. Pork consumption accounts for two percent, while beef accounts for five percent. When it comes to the caste groups, among $\mathrm{BCs}$ the most popular meats are chicken, mutton and fish, while the OC prefer mutton. Among Christians, it is chicken, mutton and fish, and among Muslims it is chicken, mutton, beef and fish. Altogether, chicken, mutton and fish are the most popular meats eaten by respondents. Eighty percent of respondents eat meat on a weekly basis, while about 10 percent eat meat either on a daily or monthly basis. The general trend is the higher the income, the lower the frequency of meat-eating. Twenty-five percent of respondents answered that they eat meat because it is healthy, 20 percent because it is healthy and tasty, and another important reason is family, that is, meat-eating together in families. The survey shows that 85 percent of respondents' households eat meat, while 15 percent of households do not and thus not all households of meat-eating respondents eat meat. Forty percent reported buying meat at the butcher's, 15 percent at wet/farmers markets, 10 percent online and 10 percent in hypermarkets. The higher their income, the more likely respondents are to buy meat at hypermarkets and not at wet markets or butcher's shops. Eggs can be considered veg as well as non-veg by different Hindu groups and the survey shows that about 90 percent eat eggs, including vegetarians.

Respondents were asked about their familiarity with the green and brown logos issued by FSSAI, and the responses show that 75 percent are not familiar with these logos. Respondents were also asked about the relationship between the BJP and vegetarianism, that is, to what extent BJP politicians can be considered vegetarians. Forty percent believe them to be meat-eaters, 30 percent are undecided, and 30 percent believe this not to be the case. Forty percent believe that the BJP promotes vegetarianism, 35 percent do not believe this to be the case and 25 percent are undecided. To sum up on the survey, the vast majority of (Hindu) respondents are meat-eaters who listed reasons such as health, taste and family for meat-eating. Thus, regardless of age, gender, education/income and caste, the idea that meat is healthy has 
become widespread. Moreover, eggs, onion and garlic are widely consumed not only among meat-eaters but also among vegetarians. The majority of meateaters consume meat on a weekly basis, and as income levels rise meat is more frequently bought in hypermarkets where respondents come into contact with the green and brown marks. However, the vast majority of informants were not familiar with these logos. The majority of respondents believe that the BJP promotes vegetarianism and that BJP politicians are meat-eaters. These findings contrast the Indian vegetarian ideology - meat-eating is dominant across all social groups.

I now provide a glimpse into the ethnographic data from my fieldwork: The informant Arkarsh is in his early 40s and lives in a flat in Gachibowli, a booming IT suburb about 20 kilometres west of Hyderabad. He grew up in Orissa in a non-veg family and moved to Hyderabad six years ago to work to work in IT after finishing his MA in computing. Arkarsh belongs to the Kshatriya caste or Ruler Community. When we discussed veg and non-veg after going shopping one day, he explained that:

I am both. I keep on switching between veg and non-veg. I have been vegetarian for the last eight years and recently probably three months ago I started eating non-vegetarian food. It is because of my health concerns, my doctor said I am low in B12 (a vitamin that ensures the normal functioning of the brain and nervous system) and advised me to take meat. So, I am eating meat as a medicine rather than food. I have read it in the scriptures, even the Ayurveda has some meat in it. Whatever you eat you find some non-veg properties in it. In fact, from my childhood I am taking non-vegetarian, but I don't eat beef for religious reasons.

This statement reflects the sentiment among many of my informants: veg and non-veg are combined in a multitude of ways for many different reasons. Health/nutrition and spirituality are inseparable in everyday understandings and practices of veg and non-veg. However, other informants simply eat meat (even beef and pork) on a daily basis for taste reasons and not for health.

Another ethnographic example: the woman Ramya is in her 50s and she lives with her husband and two children in a flat in Hitec City not far from Arkarsh. The family migrated from West Bengal and both Ramya and her husband hold degrees in IT and now works in that sector. Ramya is a Brahmin, but she has not always been a vegetarian: 
I'm from West Bengal, a coastal area so we usually eat lots of fish. However, I had a wish to be fulfilled and if that wish should be fulfilled I promised God to give up something that is very dear to me and that's how I gave up fish some 20 years back. Since then I have been a strict vegetarian and I even quit eggs. My dad's family are veg, but my mum's side are non-veg. They're all Brahmins. My son eats non-veg, beef too-I think he found it tastes better. I think he is more into rebellion—-he makes his own choice. At home, he definitely can't cook beef.

At the core of this statement is individual choice and flexibility. Ramya explains that among all her friends she is the only vegetarian and that that is their own choice. Among these friends it's also common to be a vegetarian on Tuesdays, Thursdays or Saturdays as well as occasions like the Hindu festivals of Navaratri and Rama Navami. Ramya argues that vegetarianism is becoming far more diverse over time and jokingly explains that she received a WhatsApp message that identified eight different types of vegetarians in India. The same goes for the non-vegetarian_- "A lot of people now consider fish and eggs as vegetarian," she explains. Ramya believes that it's healthier to be a non-vegetarian: when eating "different species of animals, fried stuff and lots of oil" you also get protein.

These preliminary findings suggest that the relationship between veg and non-veg is being redefined in contemporary India: the long-held idea that the more individuals and social groups follow a vegetarian lifestyle, the higher the social status they will enjoy, is breaking down. What is more, vegetarianism and meat-eating are increasingly individual lifestyle choices rather than determined by religious orthodoxy. A key question is how Hindu consumers understand, practice and contest vegetarianism and meat-eating in their everyday lives, and my ethnography challenges the idea that class/ caste affiliation is inseparable from the veg/non-veg distinction: that is, that the higher the caste, the less likely Hindus are to eat meat and, conversely, the lower the caste, the more likely people are to consume meat. Paradoxically, these middle-class Hindus go about their everyday food consumption in the world's most standardised market for vegetarian products in which green/ brown marks are ubiquitous and can be found on billions of products and on the facades of restaurants. In fact, my survey supports statistics showing that Telangana may be the least vegetarian state in India, and this project explores why and how this may the case. 
A final ethnographic example: I am in the Star hypermarket in Gachibowli. The Star hypermarket opened in 2017, and like in all other stores across India, all food (except vegetables and meat), drinks and care products carry distinctive green or brown marks. After coming to power, Modi decreed that not only all food products but also all nutraceuticals (dietary supplements), care products and cosmetics should be labelled either green or brown. Local and multinational industry players, who have entered India in large numbers in the wake of market reforms and liberalisation starting in the 1990s, filed a lawsuit arguing that the law was rushed through without any kind of consultation, resulting in high costs and highly complex implementation challenges. In the Star hypermarket, as well as hypermarkets such as Spar, a wide range of fresh meat and (live) fish are readily available for consumers to buy. And they certainly do: during my fieldwork in Hyderabad and Delhi, lines in front of the meat sections in these hypermarkets are often long, and hypermarket managers told me that the sale of meat is booming, including among new groups of consumers who were traditionally vegetarians. In the Spar hypermarket that opened in central Hyderabad in 2007, the meat/fish section is still enclosed behind a glass wall that clearly sets it off from the main shopping area. The side of the glass wall that faces the main shopping area is lined with vegetarian products from Organic India (the country's largest producer of organic products that are also marketed internationally). Thus, the division between the meat/ fish on one side and the main shopping area on the other is clearly marked and "fortified" by "green" Organic India products that appeal to many middleclass consumers. In the recently opened Gachibowli hypermarkets, there is no wall between the meat/fish sections and the main shopping area, and the reason for this is twofold: first, meat and its consumption are becoming more and more accepted in India, even among Hindu groups that were traditionally vegetarian; and second, new hypermarkets are designed to accommodate the sale of meat/fish. In these hypermarkets, chicken in particular is promoted as healthy and wholesome on posters in the meat sections and this resonates with the survey and informant, Arkarsh, discussed previously.

The whole story is visible in the Indian hypermarkets: we see how neoliberal reforms and the intensified globalisation of food markets has led to a vast pluralisation of shopping desires and choices; how religious, vegetarian/ vegan, and "green" protests and regulations struggle to keep up with but also legitimise production, trade and consumption; and how large and growing numbers of middle-class Hindu consumers are confronted with all these vast changes on a daily basis. 
I pay specific attention to sanitised forms of vegetarianism that are not necessarily related to meat, that is, the revolution in the processed food sector, but also non-food products such as health supplements and care products such as toothpaste that are also subjected to new forms of regulation. At the same time, meat is all-important: so-called cow lynchings are frequent in India. In most cases, Muslims are accused of mistreating or eating holy cows, and are then lynched by Hindu mobs. Beef is hotly debated in Telangana, and on many occasions, Dalit groups have been attacked verbally and physically when advocating for their right to eat and celebrate beef and beef festivals (Natrajan 2018).

\section{CONCLUSION}

To sum up on the review of the veg/non-veg literature, the vast majority of studies focus on vegetarianism and not so much on meat-eating. At the same time, empirical data for the studies was, for the most part, generated before the super/hypermarket revolution that has taken place within the last decade or so, and no studies explore green/brown regulation from 2011 onwards. Existing studies of vegetarianism in India conventionally explore Hindu disgust and fascination with traditional meat markets in the bazaar, or vegetarianism in Hindu philosophy. The predominant literature on vegetarianism in India mostly explores microsocial aspects such as everyday consumption among Hindu groups and, to a lesser extent, public vegetarianism as an effect of "gastropolitics," that is, how beliefs about food encode complex sets of social and moral propositions. What is more, most studies explore individual and group food consumption and not the surrounding markets and regulation. In both political/public discourses, as well as scholarly studies, Hindu meat-eating is often seen as exceptional and/or generated by certain ritual or religious circumstances rather than as an everyday practice. Given impetus by Hindu nationalism, four issues seem to condition the nationalisation of Hinduism and Hinduness on the one hand and vegetarianism as proper Hindu practice on the other: cow veneration; banning of cow slaughter; vegetarian regulation in the form of green/brown marks; as well as India being a major producer of meat and water buffalo beef in particular. However, most studies tend to assume that vegetarianism may be relatively stable and intact among higher caste groups in Indian states or locations such as Gujarat and Rajasthan where vegetarianism is widespread among Hindu groups, are representative of India 
as a whole, and my quantitative as well as qualitative data has shown this not to be the case. The informant Ramya explained that the eating of fish is widespread in West Bengal and several other informants supported this. Thus, most anthropological studies of vegetarianism and cow veneration focus on states and contexts where vegetarianism is relatively stable among most of the population.

Meat-eating and vegetarianism alike are commercialised and standardised in contemporary India. Both veg and non-veg can function as markers of new, mobile middle-class Hindu identities and are promoted by some Hindu groups as Indian "Hindu virtues" in which veg can be associated with a proper and pure lifestyle, whereas meat signifies social mobility, prestige and nutrition. Controversies over what Hinduism is, or ought to be, are intensifying between elite/nationalist ideology and everyday practices as meat-eating is becoming more and more common and standardised. As we saw above, in the case of the informant Arkarsh, for example, health is often evoked when respondents and informants explain why they eat meat: a form of purification (of the body) whereby disjunctive features of life are eliminated and substituted by wholeness - especially in the context of rapid transformations such as migration, urbanisation, social mobility and individualisation that I have explored in the context of the intensifying retail revolution and changing consumer culture in contemporary India. Among my informants, "health" is generally used in a discourse encompassing Western scientific ideas about nutrition and not so much spiritual/ritual pollution/ purity. All these transformations condition veg and non-veg, and nowhere in India are these trends more noticeable than in Hyderabad. I have provided a glimpse into the empirical data from my fieldwork, but much more empirical data is needed in order fill the gap in existing knowledge about the complex and changing relationship between veg and non-veg.

\section{NOTES}

* Johan Fischer is Associate Professor in the Department of Social Sciences and Business, Roskilde University, Denmark. His work focuses on modern religion and consumer culture. More specifically, Johan explores the interfaces between class, consumption, market relations, religion and the state in a globalised world. A central focus in this research is the theoretical and empirical focus on the proliferation of religious commodities and services on a global scale. He is the author of Proper Islamic Consumption: Shopping among the Malays in Modern Malaysia (NIAS Press 2008), The Halal Frontier: Muslim Consumers in a Globalized Market (Palgrave Macmillan 2011), Islam, Standards, and Technoscience: In Global Halal Zones (Routledge 
2015), Halal Matters: Islam, Politics and Markets in Global Perspective (Routledge 2015), Religion, Regulation, Consumption: Globalising Kosher and Halal Markets (Manchester University Press 2018) and Kosher and Halal Business Compliance (Routledge 2018) as well as articles in journals and edited volumes. He is the Series Editor on Springer's book series Asia in Transition, on the International Editorial Board of International Journal of Asia Pacific Studies and on the Editorial Advisory Board of British Food Journal. Currently, he is working on a research project that explores the relationship between vegetarian and non-vegetarian food markets in India.

** This research was supported by The Danish Council for Independent Research (Social Sciences)

\section{REFERENCES}

Ahmad, Z. 2013. Marginal occupations and modernising cities. Economic \& Political Weekly 48 (32): 121-131.

Alsdorff, L. 2010 [1962]. The history of vegetarianism and cow-veneration in India. London and New York: Routledge.

Alter, J. S. 2000. Sex, diet, and the politics of nationalism. Philadelphia: Penn Press.

Anjaria, J. S. 2016. The slow boil: Street food, rights and public space in Mumbai. Stanford: Stanford University Press.

Appadurai, A. 1981. Gastro-politics in Hindu South Asia. American Ethnologist 8 (3): 494-511, https://doi.org/10.1525/ae.1981.8.3.02a00050.

1988. How to make a national cuisine: Cookbooks in contemporary India. Comparative Studies in Society and History 30 (1): 3-24, https://doi.org/10.1017/ S0010417500015024.

Babb, L. 2004. Alchemies of violence: Myths of identity and the life of trade in Western India. New Delhi, Thousand Oaks and London: Sage Publications, https://doi. org/10.4135/9788132103219.

Balibar, E. 1991. The nation form: History and ideology. In Race, nation, class: Ambiguous identities, eds. Balibar, E. and Wallerstein, E., 86-106. London: Verso.

Baviskar, A. 2012. Food and agriculture. In The companion to modern Indian culture, eds. Dalmia, V. and Sadana, R., 49-66. Cambridge: Cambridge University Press, https://doi.org/10.1017/CCOL9780521516259.005.

Baviskar, A. and Ray, R. 2011. Elite and everyman: The cultural politics of the Indian middle classes. London and New York: Routledge.

Caplan, P. 2001. Food in middle-class Madras households from the 1970s to the 1990s. In Asian food: The global and the local, eds. Cwiertka, K. and Walraven, B., 46-62. Honolulu: University of Hawaii Press.

2008. Crossing the veg/non-veg divide: Commensality and sociality among the middle classes in Madras/Chennai. South Asia: Journal of South Asian Studies 31 (1): 118-142, https://doi.org/10.1080/00856400701874742.

Chigateri, S. 2008. Glory to the cow: Cultural difference and social justice in the food hierarchy in India. South Asia: Journal of South Asian Studies 31 (1): 10-35, https://doi.org/10.1080/00856400701874692. 
Cohen, L. 2004. A consumers' republic: The politics of mass consumption in postwar America. New York: Vintage Books.

Coveney, J. 2000. Food, morals and meaning: The pleasure and anxiety of eating. London and New York: Routledge.

Desai, A. 2008. Subaltern vegetarianism: Witchcraft, embodiment and sociality in central India. South Asia: Journal of South Asian Studies 31 (1): 96-117, https://doi. org/10.1080/00856400701874734.

Devi, S. M. et al. 2014. An outline of meat consumption in the Indian population - A pilot review. Korean Journal for Food Science of Animal Resources 34 (4): 507-515, https://doi.org/10.5851/kosfa.2014.34.4.507.

Dholakia, N and Sinha, P. K. 2005. Observations on observation in India's dynamic urban markets. Forum for Qualitative Research 6 (13), Art. 13.

Dittrich, C. 2009. The changing food scenario and the middle classes in the emerging megacity of Hyderabad, India. In The new middle classes: Globalizing lifestyles, consumerism and environmental concern, eds. Meier, L. and Lange, H, 269-280. New York: Springer, https://doi.org/10.1007/978-1-4020-9938-0_15.

Dolphijn, R. 2006. Capitalism on a plate: The politics of meat eating in Bangalore, India. Gastronomica: The Journal of Critical Food Studies 6 (3): 52-59, https://doi.org/ 10.1525/gfc.2006.6.3.52.

Donner, H. 2008. New vegetarianism: Food, gender and neo-liberal regimes in Bengali middle-class families. South Asia: Journal of South Asian Studies 31 (1): 143-169, https://doi.org/10.1080/00856400701874759.

Dragsdahl, R. 2016. The practices of Indian vegetarianism in a world of limited resources: The case of Banguluru. In Food consumption in the city, eds. Sahakian, M., Saloma, C. and Suren, E., 141-158. London and New York: Routledge.

Dumont, L. 1966. Homo hierarchichus: The caste system and its implications. New Delhi: Oxford University Press.

Fanselow, F. S. 1990. The bazaar economy or how bizarre is the bazaar really? Man 25: 250-65, https://doi.org/10.2307/2804563.

Fernandes, L. 2000. Nationalizing 'the global': Media images, cultural politics and the middle class in India. Media, Culture and Society 22: 611-28, https://doi. org/10.1177/016344300022005005. .2006. India's new middle class: Democratic politics in an era of economic reforms. Minneapolis: University of Minnesota Press.

Fiddes, N. 1991. Meat: A natural symbol. London and New York: Routledge.

Food Safety and Standards Agency India/Ministry of Health and Family Welfare. 2011. Notification. New Delhi: Ministry of Health and Family Welfare.

Freed, S. et al. 1981. Sacred cows and water buffalo in India: The uses of ethnography. Current Anthropology 22 (5): 483-502, https://doi.org/10.1086/202723.

Fuller, C. 1992. The camphor flame: Popular Hinduism and society in India. Princeton: Princeton University Press.

Fuller, C. and Narasimhan, H. 2007. Information technology professionals and the newrich middle class in Chennai (Madras). Modern Asian Studies 41 (1): 121-150, https://doi.org/10.1017/S0026749X05002325.

Ghassem-Fachandi, P. 2012. Pogrom in Gujarat: Hindu nationalism and anti-Muslim violence in India. Princeton: Princeton University Press. 
Giridharadas, A. 2011. India calling: An intimate portrait of a nation's remaking. New York: Times Books.

Gupta, A. 2003. Postcolonial developments: Agriculture in the making of modern India. Durham, NC and London: Duke University Press.

Hansen, T. B. 1996. The ethics of Hindutva and the spirit of capitalism. In The BJP and the compulsions of politics in India, eds. Hansen, T. B. and Jaffrelot, C., 291-314. New Delhi: Oxford University Press, https://doi.org/10.1215/9780822381273-001. 1999. The saffron wave: Democracy and Hindu nationalism in modern India. Princeton: Princeton University Press.

Hansen, T. B. and Stepputat, F. 2001. Introduction: States of imagination. In States of imagination: Ethnographic explorations of the postcolonial state, eds. Hansen, T. B. and Stepputat, F., 1-41. Durham, NC and London: Duke University Press.

Harris, M. 1977. Cannibals and kings: The origins of cultures. New York: Random House. Jaffrelot, C. 2017. India's democracy at 70: Towards a Hindu state? Journal of Democracy 28 (3): 52-63, https://doi.org/10.1353/jod.2017.0044.

Kaur, R. and Hansen, T. B. 2016. Aesthetics of arrival: Spectacle, capital, novelty in post-reform India. Identities 23 (3): 265-275, https://doi.org/10.1080/107028 9X.2015.1034135.

Khare, R. S. 1966. A case of anomalous values in Indian civilization: Meat-eating among the Kanya-Kubja Brahmans of Katyayan Gotra. The Journal of Asian Studies 25 (2): 229-240, https://doi.org/10.2307/2051325.

Klein, J. A. 2008. Afterword: Comparing vegetarianisms. South Asia: Journal of South Asian Studies 31 (1), 199-212, https://doi.org/10.1080/00856400701874767.

Leroy, F. and Praet, I. 2015. Meat traditions: The co-evolution of humans and meat. Appetite 90: 200-211, https://doi.org/10.1016/j.appet.2015.03.014.

Maiorano, D. 2015. The politics of economic reforms in India. In Routledge handbook of contemporary India, ed. Jacobsen, K. A., 203-215. London and New York: Routledge.

Malamoud, C. 1996. Cooking the world: Ritual and thought in ancient India. New Delhi: Oxford University Press.

Marriott, M. 1976. Hindu transactions: Diversity without dualism. In Transaction and meaning: Directions in the anthropology of exchange and symbolic behaviour, ed. Kapferer, B., 109-142. Philadelphia: Institute for the Study of Human Issues.

Mazzarella, W. 2003. Shoveling smoke: Advertising and globalization in contemporary India. Durham and London: Duke University Press, https://doi. org/10.1215/9780822385196.

More Indians eating beef, buffalo meat. 2016. The Hindu, 29 October.

Nandy, A. 2014. A disowned father of the nation in India: Vinayak Damodar Savarkar and the demonic and the seductive in Indian nationalism. Inter-Asia Cultural Studies 15 (1): 91-112, https://doi.org/10.1080/14649373.2014.882087.

Natrajan, B. 2018. Cultural identity and beef festival: Toward a 'multiculturalism against caste.' Contemporary South Asia 26 (3): 287-304.

Nickow, A. 2015. Growing in value: NGOs, social movements and the cultivation of developmental value chains in Uttarakhand, India. Global Networks 15: 45-64, https://doi.org/10.1111/glob.12087. 
Novetzke, C. L. 2017. Non-veg. South Asia: Journal of South Asian Studies 40 (2): 366369, https://doi.org/10.1080/00856401.2017.1295546.

Osella, F. and Osella, C. 2000. Social mobility in Kerala: Modernity and identity in conflict. London: Pluto Press.

Osella, C. 2008. Introduction. South Asia: Journal of South Asian Studies 31 (1): 1-9, https://doi.org/10.1080/00856400701874684.

Parvathi, P. and Waibel, H. 2016. Organic agriculture and fair trade: A happy marriage? A case study of certified smallholder black pepper farmers in India. World Development 77: 206-220, https://doi.org/10.1016/j.worlddev.2015.08.027.

Pingali, P. and Khwaja, Y. 2004. Globalisation of indian diets and the transformation of food supply systems. ESA Working Paper No. 04-05. Rome: FAO.

Rao, C. N. et. al. 2016. Organised retailing and agro-business: Implications on new supply chains on the Indian economy. New York: Springer.

Ray, K. and Srinivas, T. 2012. Curried cultures: Globalization, food and South Asia. California: University of California Press.

Robbins, P. 1999. Meat matters: Cultural politics along the commodity chain in India. Cultural Geographies 6 (4): 399-423.

Roy, P. 2002. Meat-eating, masculinity and renunciation in India: A Gandhian grammar of diet. Gender \& History 14 (1): 62-91, https://doi.org/10.1111/1468-0424.00252.

Sadana, R. A. 2007. Suitable text for a vegetarian audience: Questions of authenticity and the politics of translation. Public Culture 19 (2): 307-328.

Simoons, F. J. 1994. Eat not this flesh: Food avoidances from prehistory to the present. Madison and London: University of Wisconsin Press.

Srivastava, S. 2017. Divine markets: Ethnographic notes on post-nationalism and consumption in India. In Religion and the morality of the market, eds. Rudnyckyj, D. and Osella, F., 94-115. Cambridge: Cambridge University Press, https://doi.org/ 10.1017/9781316888704.005.

Stuart, T. 2015. Bloodless revolution: A cultural history of vegetarianism from 1600 to modern times. New York: HarperCollins.

Sutton, D. 2017. Comment: Reflections on meat-eaters, vegetarians, and vampires. Ethnos 82 (2): 298-307, https://doi.org/10.1080/00141844.2015.1119173.

United States Department of Agriculture. 2016. From where the buffalo roam: India's beef exports. Washington DC: United States Department of Agriculture.

Zimmermann, F. 2011. The jungle and the aroma of meats: An ecological theme in Hindu medicine. Delhi: Motilal Banarsidass Publishers.

Zukin, S. 2004. Point of purchase: How shopping changed American culture. New York: Routledge. 